\title{
Grateloupia tenuis Wang et Luan sp. nov. (Halymeniaceae, Rhodophyta): A New Species from South China Sea Based on Morphological Observation and $r b c L$ Gene Sequences Analysis
}

\author{
Ling Yu, ${ }^{1}$ Hongwei Wang, ${ }^{1}$ and Rixiao Luan ${ }^{2}$ \\ ${ }^{1}$ College of Life Sciences, Liaoning Normal University, Dalian 116029, China \\ ${ }^{2}$ Dalian Natural History Museum, Dalian 116023, China \\ Correspondence should be addressed to Hongwei Wang; kitamiwang@163.com
}

Received 31 July 2013; Revised 16 November 2013; Accepted 18 November 2013

Academic Editor: Stefano D’Amelio

Copyright (C) 2013 Ling Yu et al. This is an open access article distributed under the Creative Commons Attribution License, which permits unrestricted use, distribution, and reproduction in any medium, provided the original work is properly cited.

Grateloupia tenuis Wang et Luan sp. nov. is a new species described from Lingshui, Hainan Province, South China Sea. Based on the external form and internal structure, combined with $r b c \mathrm{~L}$ gene sequence analysis, Grateloupia tenuis is distinct from other Grateloupia species as follows: (1) thalli is slippery and cartilaginous in texture; possess fewer branches, relatively slight main axes, and two or three dichotomous branches; (2) cortex is 5-6 layers; medulla is solid when young, but hollow in old branches; reproductive structures are dispersed in main axes of thalli and lower portions of branchlets; exhibits Grateloupia-type auxiliary cell ampullae; (3) the four studied G. tenuis sequences were positioned in a large Grateloupia clade of Halymeniaceae, which included sister group generitype G. filicina with 68 bp differences; $G$. tenuis was determined to be a sister taxon to the G. catenata, G. ramosissima, G. orientalis, and G. filiformis subclade. The pairwise distances between G. tenuis and these species were 39 to $50 \mathrm{bp}$. The sequences of $G$. tenuis differed by 81-108 bp from the sequences of other samples in Grateloupia; there are 114-133 bp changes between G. tenuis and other genera of Halymeniaceae. In final analysis, we considered Grateloupia tenuis Wang et Luan sp. nov. to be a new species of genus Grateloupia.

\section{Introduction}

Red algae Grateloupia C. Agardh is a species-rich genus in the family Halymeniaceae, which not only exhibits highly diverse external morphology, but also is one of the genera in which species discrimination is more difficult. This genus is widely distributed in tropical and temperate coastal areas and includes more than 80 species worldwide and a total of 35 species in China [1-12]. The genus Grateloupia was originally built on the foundation of three species, namely, G. ornata, G. hystrix, and G. filicina, with G. filicina identified as the genus generitype [13].

Species morphology is significantly varied in Grateloupia, determining difficulties in species identification and controversy in species classification between algae taxonomists. Yendo [14] described Grateloupia with lomentaceous features as "catenate" and proposed G. catenata as a new species; however, Howe [15] regarded Grateloupia with lomentaceous characteristics as G. filicina (Lamouroux) C. Agardh var. lomentaria Howe. Okamura [16] opined that G. filicina var. lomentaria was a mature stage of G. filicina var. porracea, and integrated them into G. filicina var. porracea f. lomentaria (Howe) Okamura, with G. catenata being a synonym. Wang et al. [1] inspected type material of G. catenata Yendo and proposed to reinstate the Yendo name. G. ramosissima Okamura was discovered by Lin et al. [9], and its morphology resembles the algae researched in the present study. G. orientalis was described based on studies of cystocarp development and $r b c \mathrm{~L}$ gene sequence analysis [9]. Zhang et al. [12] confirmed a new record of $G$. orientalis in the Hainan province of China through morphological observations, development of reproductive structures and molecular phylogenetic studies.

In our current research, the above species (G. filicina, $G$. catenata, G. ramosissima and G. orientalis) showed close relationships with G. tenuis; however, due to the particularly large differences in external and internal morphologies between $G$. 
tenuis and other known algae, this species has not been mentioned in previous reports. Based on these differences and analysis of ribulose-1,5-bisphosphate carboxylase/oxygenase $(r b c \mathrm{~L})$ gene sequences, we recommend that this alga is a new species of Grateloupia and should be defined as Grateloupia tenuis Wang et Luan sp. nov.

\section{Materials and Methods}

2.1. Morphological Analysis. Specimens were collected from the coast of Lingshui, Hainan Province, South China Sea (5 February 2009, leg. R. X. Luan; LNU20092087, LNU20092088, LNU20092089, and LNU20092090). Voucher herbarium specimens are reserved in the Herbarium of the College of Life Sciences, Liaoning Normal University, Dalian, China (LNU). We took G. tenuis (LNU20092088) as the holotype.

Morphological observations were made on algal specimens preserved in $10 \%$ seawater or pressed on herbarium sheets, and molecular analysis was conducted on samples desiccated in silica gel. Photographs of the holotype specimen were taken with a Canon EOS 650D (Canon, Japan). Hand sections were made by cryostat microtome, stained with $0.5 \%(\mathrm{w} / \mathrm{v})$ cotton blue and discolored with $45 \%$ acetic acid. Photomicrographs were taken on an Olympus $\mathrm{BH} 2$ digital camera (Olympus Beijing Co. Ltd., China) mounted on a Nikon microscope (Nikon Corporation, Japan).

\subsection{DNA Extraction and Phylogenetic Tree Construction.} DNA samples of LNU20092087, LNU20092088, LNU20092089, and LNU20092090 were extracted using the DNeasy Plant Mini Kit (QIAGEN, Valencia, CA, Beijing). The procedures for PCR amplification and sequencing were executed as described previously [1]. The $r b c \mathrm{~L}$ gene sequences of 32 extra relevant Halymeniaceae species and two additional related family (Gelidiaceae and Gracilariaceae) species were selected from GenBank for analysis and were involved in the alignment (Table 1). Gelidiella ligulata Dawson and Gracilaria tenuistipitata Chang et Xia were treated as outgroups.

The $r b c \mathrm{~L}$ sequences were aligned and compiled with Clustal X version 1.83 [21] for phylogenetic analysis. Phylogenetic tree construction and nucleotide differences analyses were conducted using MEGA 5.0. Maximum parsimony (MP), neighbor joining (NJ), and maximum likelihood (ML) were adopted to construct the phylogenetic tree. The MP analysis used heuristic searches for evaluating tree likelihoods, which was carried out with 1000 replicates, employed random addition sequence of taxa and used tree-bisectionreconnection (TBR) branch swapping [22]. The NJ analysis used the ratio test for estimation to seek optimal settings and ensure data dependability and was performed with Modeltest version 3.06 [23]. For ML analysis, a variety of cumulatively complex models of molecular evolution were assessed, as summarized by Litaker et al. [24] and Moncalvo et al. [21]. Bootstrap support values were calculated using 1000 samplings of the dataset [25] to estimate statistical reliability for MP, NJ, and ML methods.

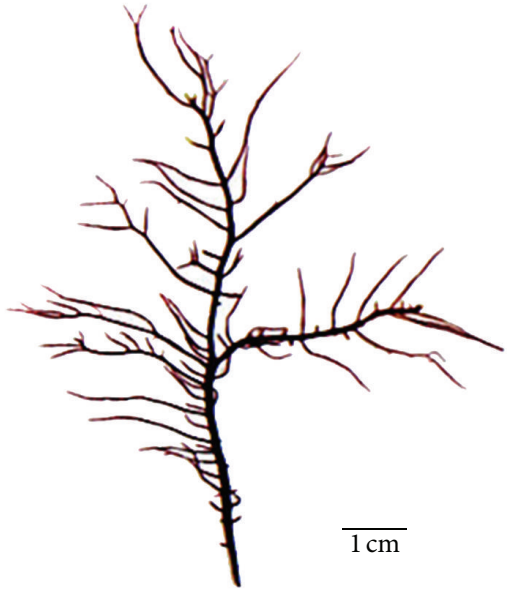

FIGURE 1: Holotype specimen of Grateloupia tenuis (female gametophyte collected from Lingshui, LNU20092088).

\section{Results}

3.1. Taxonomic Descriptions. Thallus simplex, linear, purplish red in color, cartilaginous and slippery in texture, $4-7 \mathrm{~cm}$ in height, main axes about $1 \mathrm{~mm}$ in width, branches about $0.2-0.6 \mathrm{~mm}$ in width, with fewer branches than other thalli (Figure 1). Main axes of thalli and branches relatively slight, erect axes cylindrical or subcylindrical and bearing alternation or second branches, twice or thrice dichotomously branched (Figures 2(a) and 2(b)). Cortex 5-6 layers, cells elliptic or polygonal and arranged densely; medulla solid with relatively intensive filaments when young, but hollow in the center in old branches. Gametophytes dioecious with reproductive structures dispersed in main axes of thalli and lower portion of branches, and cystocarps of main axes significantly fewer than branches (Figures 2(a)-2(c)). Carposporangium developed from gonimoblasts cells, profoundly immersed inside medulla and revolved by branched ampullar filaments. Mature cystocarps $90-110 \mu \mathrm{m}$ in diameter. Spermatangium shaped from outermost cortex cells of male gametophytes. Mature tetrasporangium cruciately partitioned, $10-16 \mu \mathrm{m}$ long, $6-8 \mu \mathrm{m}$ in diameter, and inserted in outer cortical cells. Consider the following.

Etymology; "tenuis" refers to the morphology of the thallus.

Holotype; appointed here is a female specimen (LNU20092088 Figure 1).

Type locality; Lingshui, Hainan Province, China, 5 Feb. 2009, collected by R. X. Luan.

Habitat and seasonality; plant collections were seasonal from January to March, and were attached on rocky reefs or stony marsh of coastal intertidal zone.

Distribution; currently only known in Lingshui, Hainan Province, China (E109.9 $9^{\circ}$ N18.4 $4^{\circ}$.

3.2. Vegetative and Reproductive Structures. Cross-section of the thallus showed a densely arranged cortex and solid 
TABLE 1: List of species for $r b c \mathrm{~L}$ sequences analysis, collection data, and accession numbers in GenBank.

\begin{tabular}{|c|c|c|}
\hline Species & $\begin{array}{l}\text { Collection data (location, site, and } \\
\text { reference) }\end{array}$ & GenBank accession numbers \\
\hline Grateloupia tenuis Wang et Luan & $\begin{array}{l}\text { Lingshui, Hainan Province, China } \\
\text { (LNU20092087) }\end{array}$ & КC918541 \\
\hline Grateloupia tenuis Wang et Luan & $\begin{array}{l}\text { Lingshui, Hainan Province, China } \\
\text { (LNU20092088) }\end{array}$ & KC918542 \\
\hline Grateloupia tenuis Wang et Luan & $\begin{array}{l}\text { Lingshui, Hainan Province, China } \\
\text { (LNU20092089) }\end{array}$ & КC918543 \\
\hline Grateloupia tenuis Wang et Luan & $\begin{array}{c}\text { Lingshui, Hainan Province, China } \\
\text { (LNU20092090) }\end{array}$ & КС918544 \\
\hline G. catenata Yendo & $\begin{array}{l}\text { Shimiao, Dalian, Liaoning Province, } \\
\text { China (Wang et al., 2000) }\end{array}$ & AB038617 \\
\hline G. ramosissima Okamura & $\begin{array}{c}\text { Ho Ping Island, Keel Nug, Taiwan } \\
\text { Province, China (Gavio and Fredericq, } \\
\text { 2002) [4] }\end{array}$ & AF488810 \\
\hline G. filicina (Lamouroux) C. Agardh & Livorno, Italy (Wang et al., 2000) [1] & AB055472 \\
\hline G. orientalis Lin et Liang & $\begin{array}{l}\text { Linyuan, southwestern Taiwan Province, } \\
\text { China (Lin et al., 2008) [9] }\end{array}$ & EU292744 \\
\hline G. filiformis Kutzing & $\begin{array}{c}\text { Marataizes, Espiritu Santu, Brazil (Gavio } \\
\text { and Fredericq, 2002) [4] }\end{array}$ & AF488822 \\
\hline G. carnosa Yamada et Segawa & $\begin{array}{l}\text { Oryuzako, Miyazaki Prefecture, Japan } \\
\text { (Wang et al., 2000) [1] }\end{array}$ & AB038608 \\
\hline G. stipitata J. Agardh & $\begin{array}{l}\text { Lee Bay, Stewart Island, New Zealand } \\
\text { (Gavio and Fredericq, 2002) [4] }\end{array}$ & AF488816 \\
\hline G. acuminata Holmes & $\begin{array}{l}\text { Katase, Fujisawa, Kanagawa Prefecture, } \\
\text { Japan (Kawaguchi et al, 2001) }\end{array}$ & AB055480 \\
\hline G. americana Kawaguchi et Wang & $\begin{array}{c}\text { Pigeon Point, San Matio County, } \\
\text { California, USA (De Clerck et al., 2005) } \\
\text { [7] }\end{array}$ & AY772037 \\
\hline G. asiatica Kawaguchi et Wang & $\begin{array}{l}\text { Qingdao, Shandong Province, China } \\
\text { (Kawaguchi et al., 2001) [3] }\end{array}$ & AB055488 \\
\hline G. livida (Harvey) Yamada & $\begin{array}{l}\text { Izu-misaki, Miyake Island, Tokyo, Japan } \\
\text { (Wang et al., 2000) [1] }\end{array}$ & AB038610 \\
\hline G. patens (Okamura) Kawaguchi et Wang & $\begin{array}{l}\text { Oohara, Chiba Prefecture, Japan (Wang } \\
\text { et al., 2001) [2] }\end{array}$ & AB061392 \\
\hline G. divaricata Okamura & $\begin{array}{l}\text { Oshoro, Hokkaido, Japan } \\
\text { (Wang et al., 2000) [1] }\end{array}$ & AB038609 \\
\hline G. schmitziana (Okamura) Kawaguchi et Wang & $\begin{array}{l}\text { Shichirigahama, Kamakura, Kanagawa, } \\
\text { Japan (Wang et al., 2000) [1] }\end{array}$ & AB061398 \\
\hline G. lanceolata (Okamura) Kawaguchi & $\begin{array}{l}\text { Shikanoshima, Fukuoka, Japan } \\
\text { (Kawaguchi et al., 2001) [3] }\end{array}$ & AB055477 \\
\hline G. elliptica Homles & $\begin{array}{c}\text { Goshikinohama, Usa, Tosa, Kochi } \\
\text { Prefecture, Japan (Kawaguchi et al., 2001) } \\
\text { [3] }\end{array}$ & AB055476 \\
\hline G. kurogii Kawaguchi & $\begin{array}{l}\text { Saikai-bashi, Nagasaki Prefecture, Japan } \\
\text { (Wang et al., 2001) [2] }\end{array}$ & AB038606 \\
\hline G. phuquocensis Tanaka et Pham-Hoang & $\begin{array}{l}\text { Kaalawai, Oahu, Hawaii (De Clerck et al., } \\
\text { 2005) [6] }\end{array}$ & AY772022 \\
\hline G. sparsa (Okamura) Chiang & $\begin{array}{l}\text { Oohara, Chiba Prefecture, Japan (Wang } \\
\text { et al., 2000) [1] }\end{array}$ & AB055473 \\
\hline G. imbricata Holmes & $\begin{array}{l}\text { Tsuyazaki, Fukuoka Prefecture, Japan } \\
\text { (Wang et al., 2000) [1] }\end{array}$ & AB038607 \\
\hline G. longifolia Kylin & $\begin{array}{l}\text { Yzerfonteyn, Western Cape Province, } \\
\text { South Africa (De Clerck et al., 2005) [6] }\end{array}$ & AY772023 \\
\hline
\end{tabular}


TABle 1: Continued.

\begin{tabular}{|c|c|c|}
\hline Species & $\begin{array}{l}\text { Collection data (location, site, and } \\
\text { reference) }\end{array}$ & GenBank accession numbers \\
\hline G. belangeri (Bory de Saint-Vincent) Setchell et Gardner & $\begin{array}{l}\text { Platboom, Western Cape Province (De } \\
\text { Clerck et al., 2005) [6] }\end{array}$ & AY772027 \\
\hline G. angusta (Okamura) Kawaguchi et Wang & $\begin{array}{l}\text { Miyanoura, Hirado Island, Nagasaki } \\
\text { Prefecture, Japan (Wang et al., 2001) [2] }\end{array}$ & AB061380 \\
\hline G. capensis De Clerck & South Africa (De Clerck et al., 2005) [6] & AJ868465 \\
\hline G. somalensis Hauck & $\begin{array}{l}\text { Plage de Monseigneur, Fort Dauphin, } \\
\text { Madagascar (De Clerck et al., 2005) [7] }\end{array}$ & AY772021 \\
\hline G. taiwanensis Lin et Liang & $\begin{array}{l}\text { Northeastern and southern Taiwan (Lin } \\
\text { et al., 2008) [9] }\end{array}$ & EU292742 \\
\hline G. subpectinata Holmes & $\begin{array}{l}\text { Irago-misaki, Atsumi, Aichi, Japan (Faye } \\
\text { et al., 2004) [5] }\end{array}$ & AB114213 \\
\hline G. turuturu Yamada & $\begin{array}{l}\text { Muroran, Hokkaido, Japan, South Africa } \\
\text { (Wang et al., 2000) [1] }\end{array}$ & AB038611 \\
\hline Halymenia durvillei Bory & $\begin{array}{c}\text { Beruwela, Sri Lanka (De Clerck et al. } \\
\text { 2005) [6] }\end{array}$ & AY772020 \\
\hline Halymenia floresia (Clemente) C. Agardh & $\begin{array}{l}\text { Pulau Rebak Besar, Langkawi, Kedah, } \\
\text { Malaysia (Wang et al., 2000) [1] }\end{array}$ & АВ038603 \\
\hline Polyopes constrictus (Turner) J. Agardh & $\begin{array}{l}\text { Point Lonsdale, Victoria, Australia } \\
\quad \text { (Kawaguchi et al., 2001) [3] }\end{array}$ & AB055468 \\
\hline Polyopes lancifolius (Harvey) Kawaguichi et Wang & $\begin{array}{l}\text { Inoshiri, Usa, Tosa, Kochi, Japan } \\
\text { (Kawaguchi et al., 2002) [17] }\end{array}$ & AB084543 \\
\hline Gelidiella ligulata Dawson & $\begin{array}{l}\text { Miyake Island, Tokyo, Japan (Shimada et } \\
\text { al., 1998) [18] }\end{array}$ & AB017678 \\
\hline Gracilaria tenuistipitata Chang et Xia & Viet Nam (Gurgel et al., 2008) [19] & EU380718 \\
\hline
\end{tabular}

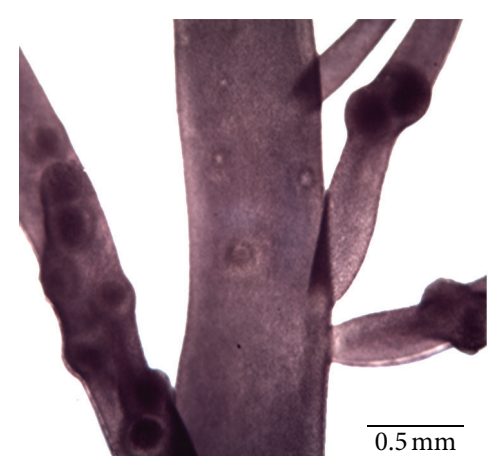

(a)

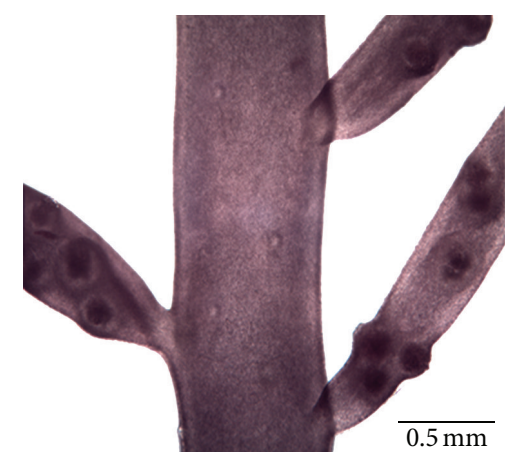

(b)

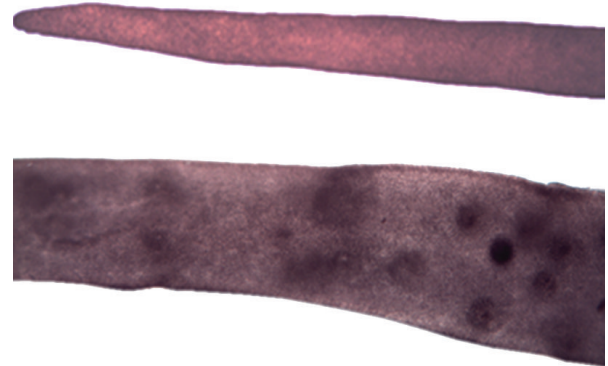

$\overline{0.5 \mathrm{~mm}}$

(c)

FIGURE 2: Branching characteristics and distribution of reproductive structures. (a) Second branches and distribution of cystocarp. (b) Alternation branches and distribution of cystocarp. (c) Cystocarp only dispersed in lower portion of branches.

medulla with dense filaments when young, but hollow in the center in old branches (Figures 3(a) and 3(b)). The 5-6 layers of the cortex consisted of oval outer layers cells arranged in neat rows and three to four inner layers of elliptic or rounded cells; the medulla was composed of slender medullary filaments $11-17 \mu \mathrm{m}$ long and $1-2 \mu \mathrm{m}$ wide, which exhibited irregular distribution (Figure 3(c)). The thallus had Grateloupia-type auxiliary cell ampullae. Auxiliary cells (ac) and carpogonial branches were produced in independent ampulla initiated from inner cortical cells. Two-celled carpogonial branches existed in each carpogonial branch ampulla and contained a terminal carpogonium and hypogynous cell (Figure 3(d)). The auxiliary cell ampullae were narrowly bottle-shaped and comprised of two or three secondary filaments. The mature auxiliary cell (ac) was elliptical in shape and obviously larger than other ampullary cells, and was located at the basal part of the ampulla (Figure 3(e)). Successive stages of the cystocarp development are displayed in Figures 3(f)-3(i). Terminal cells of the gonimoblast filaments gradually matured (Figure 3(f)). Maturing carposporangia developed from gonimoblasts cells, and were surrounded by branched ampullar filaments (Figure 3(g)). 
TABle 2: Comparison of morphological characteristics between Grateloupia tenuis and other closely related species.

\begin{tabular}{|c|c|c|c|c|c|}
\hline $\begin{array}{l}\text { Morphological } \\
\text { characteristics }\end{array}$ & G. tenuis & G. filicina & G. catenata & G. ramosissima & G. orientalis \\
\hline Thallus habit & $\begin{array}{l}\text { Fewer branches } \\
\text { and main axes } \\
\text { relatively slight; } \\
\text { two or three } \\
\text { dichotomous } \\
\text { branches; } 4-7 \mathrm{~cm} \\
\text { high }\end{array}$ & $\begin{array}{l}\text { Erect axes; several } \\
\text { terete to flattened } \\
\text { blades with } \\
\text { irregularly pinnate } \\
\quad \text { branchlets; } \\
\quad 9-12 \mathrm{~cm} \text { high }\end{array}$ & $\begin{array}{l}\text { Erect axes; terete to } \\
\text { compressed } \\
\text { branches and } \\
\text { tapering towards } \\
\text { tapex; up to } 35 \mathrm{~cm} \\
\text { high }\end{array}$ & $\begin{array}{l}\text { Erect axes; linear to } \\
\text { several lanceolate } \\
\text { blades; } 13-22 \mathrm{~cm} \\
\text { high, up to } 1 \mathrm{~mm} \\
\text { wide }\end{array}$ & $\begin{array}{c}\text { Thalli terete to } \\
\text { slightly } \\
\text { compressed } \\
\text { branches bearing } \\
\text { irregularly pinnate } \\
\text { branches; } 10-16 \mathrm{~cm} \\
\text { high }\end{array}$ \\
\hline Texture & $\begin{array}{l}\text { Slippery and } \\
\text { cartilaginous }\end{array}$ & $\begin{array}{l}\text { Mucilaginous } \\
\text { and hard }\end{array}$ & Gelatinous & Cartilaginous & $\begin{array}{l}\text { Gelatinous to } \\
\text { cartilaginous }\end{array}$ \\
\hline Cortex (C) & C: 5-6 layers & C: $5-8$ layers & C: 6-14 layers & C: 8-9 layers & C: 6-9 layers \\
\hline Medullary & Hollow & Solid & Hollow & Solid & Hollow \\
\hline $\begin{array}{l}\text { Location of } \\
\text { reproductive } \\
\text { structures }\end{array}$ & $\begin{array}{l}\text { Main axes and } \\
\text { lower portions of } \\
\text { branches }\end{array}$ & $\begin{array}{l}\text { Proliferations and } \\
\text { upper portions of } \\
\text { thallus }\end{array}$ & Whole thallus & Entire thalli & $\begin{array}{l}\text { Whole thalli except } \\
\text { the basal parts }\end{array}$ \\
\hline Distribution & $\begin{array}{c}\text { Lingshui, Hainan } \\
\text { province, China }\end{array}$ & $\begin{array}{l}\text { Italy, France, } \\
\text { Spain }\end{array}$ & $\begin{array}{l}\text { China, Japan, } \\
\text { Korea }\end{array}$ & $\begin{array}{l}\text { Japan, China, } \\
\text { Korea, Vietnam, } \\
\text { Philippine }\end{array}$ & Taiwan \\
\hline Reference & This study & $\begin{array}{c}\text { Kawaguchi et al., } \\
2001[3]\end{array}$ & $\begin{array}{c}\text { Wang et al., } 2000 \\
{[1]} \\
\text { Lee et al., } 2009 \text { [20] }\end{array}$ & Lin et al., 2008 [9] & $\begin{array}{c}\text { Lin et al., } 2008 \text { [9] } \\
\text { Zhang et al., } 2012 \\
{[12]}\end{array}$ \\
\hline
\end{tabular}

As cystocarps proceeded with development, they became increasingly larger and more deeply embedded in the medulla (Figure 3(h)). Mature cystocarps were spherical or ellipsoidal and $90-110 \mu \mathrm{m}$ in diameter (Figure 3(i)). The mature cystocarp released carpospores (Figure $3(\mathrm{j})$ ). Spermatangia of the male gametophytes were shaped from the outermost cortex cells (Figure 3(k)). Mature tetrasporangia formed from the sporophyte cortical cells were cruciately partitioned, 10$16 \mu \mathrm{m}$ long, and 6-8 $\mu \mathrm{m}$ in diameter (Figure 3(1)).

3.3. Molecular Analysis. In the phylogenetic tree, we compared four $G$. tenuis $r b c \mathrm{~L}$ gene sequences with a total of 34 extra $r b c \mathrm{~L}$ sequences from taxa comprising 28 species of Grateloupia, with four species from other genera (Halymenia C. Agardh and Polyopes J. Agardh) in Halymeniaceae and two species from Gelidiaceae and Gracilariaceae treated as outgroups, which were selected from GenBank for analyses (Table 1). The rbcL sequences of the four Lingshui samples were uniform. The $r b c \mathrm{~L}$ sequence alignment consisted of 1322 base pairs (bp), but since many $r b c \mathrm{~L}$ sequences were incomplete at the $5^{\prime}$ and $3^{\prime}$ ends, the first $67 \mathrm{bp}$ and last $15 \mathrm{bp}$ were excluded from analyses.

The maximum likelihood phylogenetic tree (Figure 4) was obtained through the NJ, MP, and ML analysis. The species aggregate of the ML phylogenetic tree was divided into three main clades with high bootstrap support values and included a large Grateloupia clade; a Halymenia/Polyopes clade, which were all within Halymeniaceae; and a Gelidiella/Gracilaria clade, which were in Gelidiaceae and Gracilariaceae, respectively. The four G. tenuis samples and the 28 kinds of Grateloupia genera formed together into one large clade. The Grateloupia clade was divided into a small and large clade, and $G$. tenuis formed a monophyletic group within the small clade.

The $r b c \mathrm{~L}$ analyses of pairwise base differences between $G$. tenuis and generitype G. filicina were $68 \mathrm{bp}$ changes (5.72\%). Sequences among G. tenuis and G. catenata and G. ramosissima differed by 39 bp (3.22\%) and 48 bp (3.98\%). There were $45 \mathrm{bp}(3.73 \%)$ and $50 \mathrm{bp}$ (4.17\%) differences between $G$. tenuis and $G$. orientalis and $G$. filiformis, respectively. Sequences between $G$. tenuis and other samples in Grateloupia ranged from $81-108$ bp changes (6.88\%-9.34\%). Divergence between $G$. tenuis specimens and other genera of Halymeniaceae ranged from $114-133$ bp differences $(9.86 \%-$ $11.66 \%)$. When compared to outgroups, the G. tenuis specimens exhibited $190 \mathrm{bp}$ (17.17\%) and $196 \mathrm{bp}$ (17.75\%) differences from Gracilaria tenuistipitata (Gracilariaceae) and Gelidiella ligulata (Gelidiaceae), respectively.

\section{Discussion}

The family Halymeniaceae exhibits high species richness, especially within Grateloupia, which makes taxonomic species identification difficult. Nevertheless, the formation of auxiliary cell ampullae is a remarkable characteristic for distinguishing genera within Halymeniaceae $[2,3,6,26]$.

The newly described $G$. tenuis species is morphologically similar to some species, especially G. catenata. Table 2 shows a comparison in morphological features among $G$. tenuis and the closely related species $G$. catenata, G. ramosissima, $G$. orientalis, G. filicina. It was easy to differentiate G. tenuis from $G$. catenata by its significantly smaller size (4-7 cm high compared to $35 \mathrm{~cm}$ high, resp.) and by its dispersed reproductive structures in the main axes of thalli and lower portions of branchlets compared to the scattered reproductive structures 


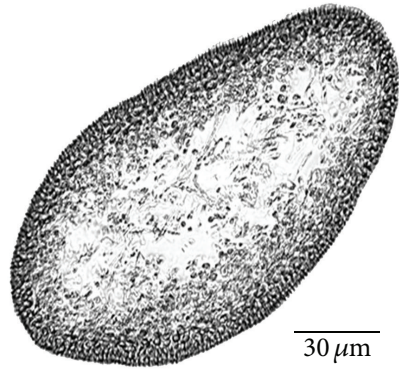

(a)

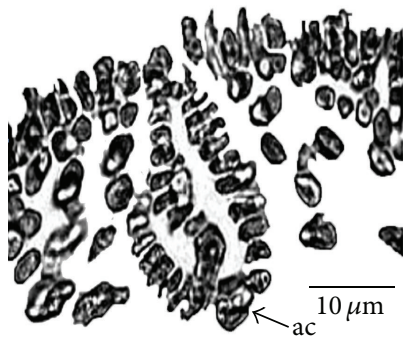

(d)

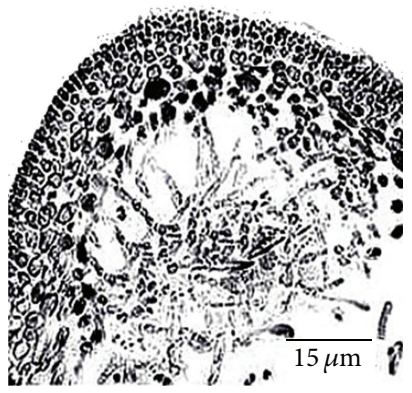

(g)

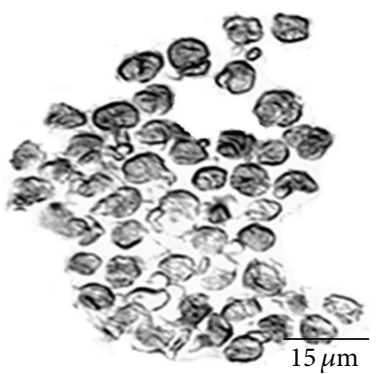

(j)

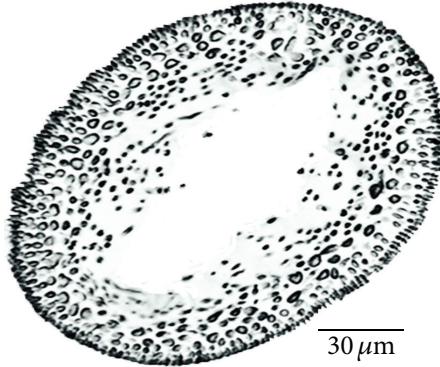

(b)

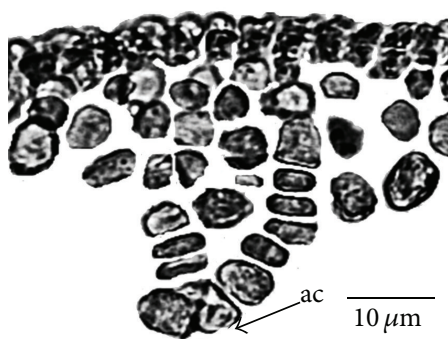

(e)

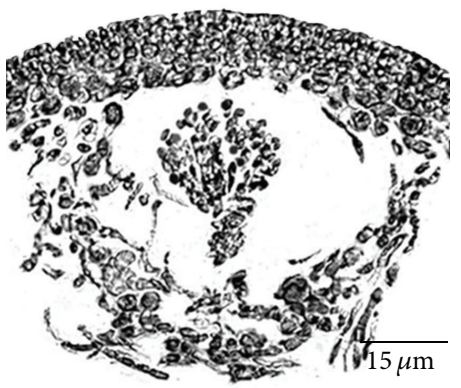

(h)

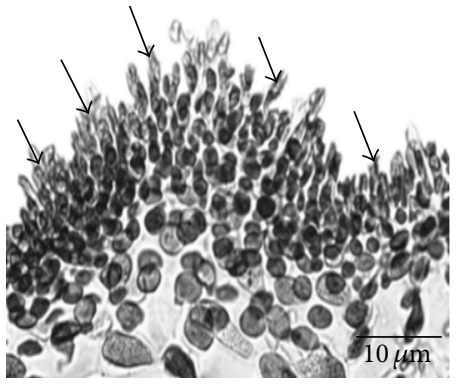

(k)

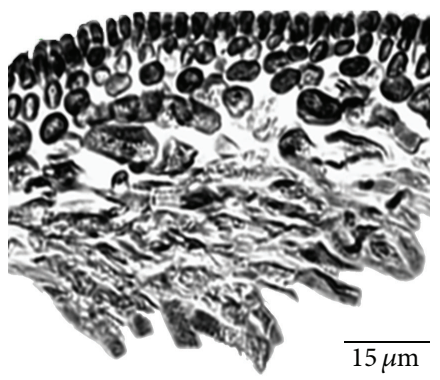

(c)

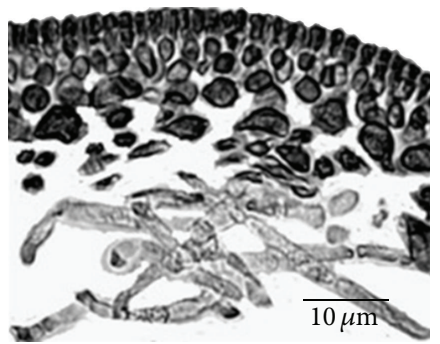

(f)

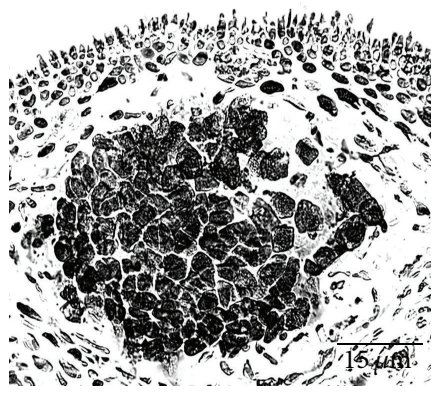

(i)

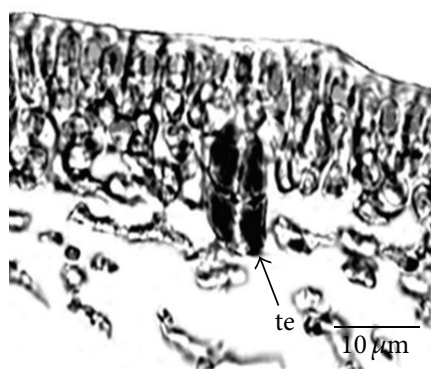

(1)

FIGURE 3: Vegetative and reproductive structures of Grateloupia tenuis. (a) Cross-section of thallus displaying cortex and solid medulla when young. (b) Cortex and hollow medulla when old. (c) Internal structure of branches displaying arrangement and layers between cortex and medulla. ((d), (e)) Structure of carpogonial branch ampulla and auxiliary cell ampulla. ((f)-(i)) Successive periods of cystocarp development. (f) Initial phase of cystocarp formation. (g) Middle phase of cystocarp formation. (h) Cystocarp development. (i) Advanced stage of cystocarp development and mature cystocarps. (j) Carpospores. (k) Construction of spermatangium. (l) Mature tetrasporangium (te).

over the whole thallus in G. catenata. It was possible to separate G. tenuis from generitype G. filicina by its slippery and cartilaginous texture compared with the mucilaginous and hard texture of G. filicina, and by its dichotomous branches compared with pinnate branchlets. Distinction with G. ramosissima and G. orientalis showed that they had abundant branches. G. tenuis also had representative Grateloupiatype auxiliary cell ampullae, which demonstrated that it was a new species of the family Halymeniaceae and pertained to the genus Grateloupia.

The $r b c \mathrm{~L}$ sequence data also strongly supported $G$. tenuis as a new species. In the ML phylogenetic tree (Figure 4), $G$. tenuis specimens were embedded in the large clade of Grateloupia and clustered into a single monophyletic group. The small clade of Grateloupia included G. catenata, G. ramosissima, G. filiformis, and G. orientalis from China, 


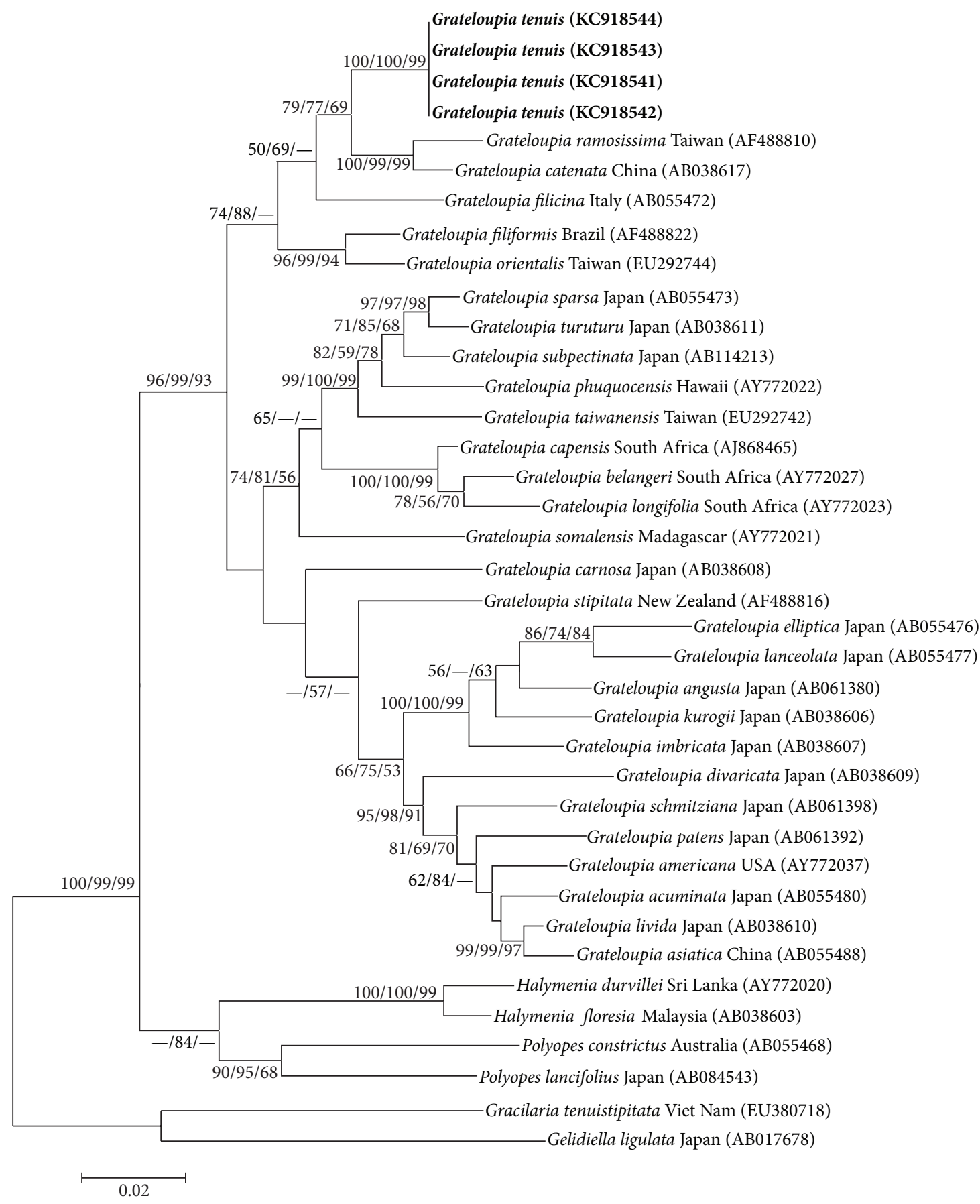

FIGURE 4: Maximum likelihood tree showing phylogenetic relationships of G. tenuis and relevant genera within Grateloupia, inferred from partial $r b c \mathrm{~L}$ gene sequences $(1240 \mathrm{bp})$. Gelidiella ligulata and Gracilaria tenuistipitata were treated as outgroups. Numbers at internal nodes are bootstrap proportion values (1000 replicates) for ML, NJ, and MP, which only show above 50\% bootstrap support. Branch lengths are proportional to the amount of sequence change. Boldface displays new species depicted in this research.

and generitype G. filicina from Italy. The G. catenata/G. ramosissima subclade was the most closely related sister taxon to $G$. tenuis and the most similar in appearance. In addition, $G$. tenuis produced a high bootstrap support value with the G. catenata/G. ramosissima subclade. The generitype species, $G$. filicina, belonged to the sister position of $G$. tenuis, which strongly supported that G. tenuis phylogenetically approached G. filicina. Moreover, G. orientalis, and G. filiformis formed a sister clade with G. tenuis. All Grateloupia species were phylogenetically different to the two clades, especially Gelidiella ligulata and Gracilaria tenuistipitata serving as outgroups. 


\section{Conclusions}

From morphological observation and $r b c \mathrm{~L}$ gene sequence analysis, we concluded that the studied specimen was a new species of genus Grateloupia, defined as Grateloupia tenuis Wang et Luan sp. nov. Currently, due to algae species diversity, traditional taxonomic methods are not the most effective way to identify species. With the rapid development of molecular biology and gene sequencing technology; however, taxonomists are increasingly using combined morphological observation with DNA barcoding for algae classification. In recent years, human impact on marine ecosystems has increased the urgent need to conserve aquatic resources, and accurate species identification is a basic prerequisite in helping protect marine algae.

\section{Acknowledgments}

The authors would like to thank Liu Miao, Guan Yun, and Li Yazhuo for technical assistance. This research was supported by the National Natural Science Foundation of China (NSFC) under Contract nos. 30870161, 31270251.

\section{References}

[1] H. W. Wang, S. Kawaguchi, T. Horiguchi, and M. Masuda, "Reinstatement of Grateloupia catenata (Rhodophyta, Halymeniaceae) on the basis of morphology and $r b c \mathrm{~L}$ sequences," Phycologia, vol. 39, no. 3, pp. 228-237, 2000.

[2] H. W. Wang, S. Kawaguchi, T. Horiguchi, and M. Masuda, "A morphological and molecular assessment of the genus Prionitis J. Agardh (Halymeniaceae, Rhodophyta)," Phycological Research, vol. 49, no. 3, pp. 251-262, 2001.

[3] S. Kawaguchi, H. W. Wang, T. Horiguchi, G. Sartoni, and M. Masuda, "A comparative study of the red alga Grateloupia filicina (Halymeniaceae) from the Northwestern Pacific and Mediterranean with the description of Grateloupia asiatica, sp. nov," Phycologia, vol. 37, no. 3, pp. 433-442, 2001.

[4] B. Gavio and S. Fredericq, "Grateloupia turuturu (Halymeniaceae, Rhodophyta) is the correct name of the non-native species in the Atlantic known as Grateloupia doryphora," European Phycologia, vol. 37, no. 3, pp. 349-360, 2002.

[5] E. J. Faye, H. W. Wang, S. Kawaguchi, S. Shimada, and M. Masuda, "Reinstatement of Grateloupia subpectinata (Rhodophyta, Halymeniaceae) based on morphology and $r b c \mathrm{~L}$ sequences," Phycological Research, vol. 52, no. 1, pp. 59-67, 2004.

[6] O. de Clerck, B. Gavio, S. Fredericq, I. Bárbara, and E. Coppejans, "Systematics of Grateloupia filicina (Halymeniaceae, Rhodophyta), based on $r b c \mathrm{~L}$ sequence analyses and morphological evidence, including the reinstatement of G. minima and the description of G. capensis sp. nov," Phycologia, vol. 41, no. 2, pp. 391-410, 2005.

[7] O. de Clerck, B. Gavio, S. Fredericq, E. Cocquyt, and E. Coppejans, "Systematic reassessment of the red algal genus Phyllymenia (Halymeniaceae, Rhodophyta)," European Phycologia, vol. 40, no. 2, pp. 169-178, 2005.

[8] R. J. Wilkes, L. M. McIvor, and M. D. Guiry, "Using $\mathrm{rbcL}$ sequence data to reassess the taxonomic position of some Grateloupia and Dermocorynus species (Halymeniaceae,
Rhodophyta) from the north-eastern Atlantic," European Phycologia, vol. 40, no. 1, pp. 53-60, 2005.

[9] S.-M. Lin, H.-Y. Liang, and M. H. Hommersand, “Two types of auxiliary cell ampullae in Grateloupia (Halymeniaceae, Rhodophyta), including G. taiwanensis sp. nov. and G. orientalis sp. nov. from Taiwan based on $r b c \mathrm{~L}$ gene sequence analysis and cystocarp development," Phycologia, vol. 44, no. 1, pp. 196-214, 2008.

[10] B. M. Xia, Flora Algarum Marinarum Sinicarum, vol. 1, Science Press, Beijing, China, 2004 (Chinese).

[11] D. Zhao, H. W. Wang, Y. W. Sheng, J. ZH. Lv, and R. X. Luan, "Morphological observation and $r b c \mathrm{~L}$ gene sequences studies of two new species, Grateloupia dalianensis H. W. Wang et D. Zhao, sp. nov. and G. yinggehaiensis H.W. Wang et R.X. Luan, sp. nov. (Halymeniaceae, Rhodophyta) from China," Acta Oceanologica Sinica, vol. 31, no. 2, pp. 109-120, 2012.

[12] W. Zhang, H. W. Wang, D. Zhao, Y. W. Sheng, and R. X. Luan, "Morphological observation and $r b c \mathrm{~L}$ gene sequence analysis of Grateloupia orientalis (Rhodophyta), a new record of the Hainan province," Marine Sciences, vol. 36, no. 7, pp. 109-116, 2012 (Chinese).

[13] C. A. Agardh, Species Algarum, vol. 1, part 2, Lundae, 1822.

[14] K. Yendo, "Novae algae japoniace," Botanical Magazine, vol. 34, pp. 1-12, 1920.

[15] M. A. Howe, “Chinese marine algae," Bulletin of Torrey Botanical Club, vol. 51, pp. 133-144, 1924.

[16] K. Okamura, Japanese Algae, Uchida-Rokakuho, Tokyo, Japan, 1936 (Japanese).

[17] S. Kawaguchi, H. W. Wang, T. Horiguchi, J. A. Lewis, and M. Masuda, "Rejection of Sinkoraena and transfer of some species of Carpopeltis and Sinkoraena to Polyopes (Rhodophyta, Halymeniaceae)," Phycologia, vol. 41, pp. 619-635, 2002.

[18] S. Shimada, T. Horiguchi, and M. Masuda, "Phylogenetic affinities of genera Acanthopeltis and Yatabella (Gelidiales, Rhodophyta) inferred from molecular analyses," Phycologia, vol. 38, pp. 528-540, 1999.

[19] C. F. Gurgel, S. Fredeircq, and J. N. Norris, "Two new flat species of Gracilaria (Gracilariales, Rhodophyta) from Brazil: G. abyssalis sp. nov. and G. brasiliensis sp. nov," Phycologia, vol. 47, pp. 249-264, 2008.

[20] J. I. Lee, H. G. Kim, P. Geraldino, I. K. Hwang, and S. M. Boo, "Molecular classification of the genus Grateloupia (Halymeniaceae, Rhodophyta) in Korea," Algae, vol. 24, pp. 231238, 2009.

[21] J.-M. Moncalvo, F. M. Lutzoni, S. A. Rehner, J. Johnson, and Y. S. R. Vilgaly, "Phylogenetic relationships of agaric fungi based on nuclear large subunit ribosomal DNA sequences," Systematic Biology, vol. 49, no. 2, pp. 278-305, 2000.

[22] S. K. Myung, C. Y. Eun, Y. K. Su, H. Kee, and M. B. Sung, "Reinstatement of Gracilariopsis chorda (Gracilariaceae, Rhodophyta) based on plastid $r b c \mathrm{~L}$ and mitochondrial cox 1 sequences," Algae, vol. 23, no. 3, pp. 209-217, 2008.

[23] D. Posada and K. A. Crandall, "Modeltest: testing the model of DNA substitution," Bioinformatics, vol. 14, no. 9, pp. 817-818, 1998.

[24] R. W. Litaker, P. A. Tester, A. Colorni, M. G. Levy, and E. J. Noga, "The phylogenetic relationship of Pfiesteria piscicida, cryptoperidiniopsoid sp. Amyloodinoum ocellatum and a Pfiesterialike dinoflagellate to other dinoflagellates and apicomplexans," Phycologia, vol. 35, no. 6, pp. 1379-1389, 1999. 
[25] J. Felsenstein, "Confidence limits on phylogenies: an approach using the bootstrap," Evolution, vol. 39, pp. 783-791, 1985.

[26] Y. M. Chiang, "Morphological studies of red algae of the family Cryptonemiaceae," University of California Publications in Botany, vol. 58, pp. 1-95, 1970. 

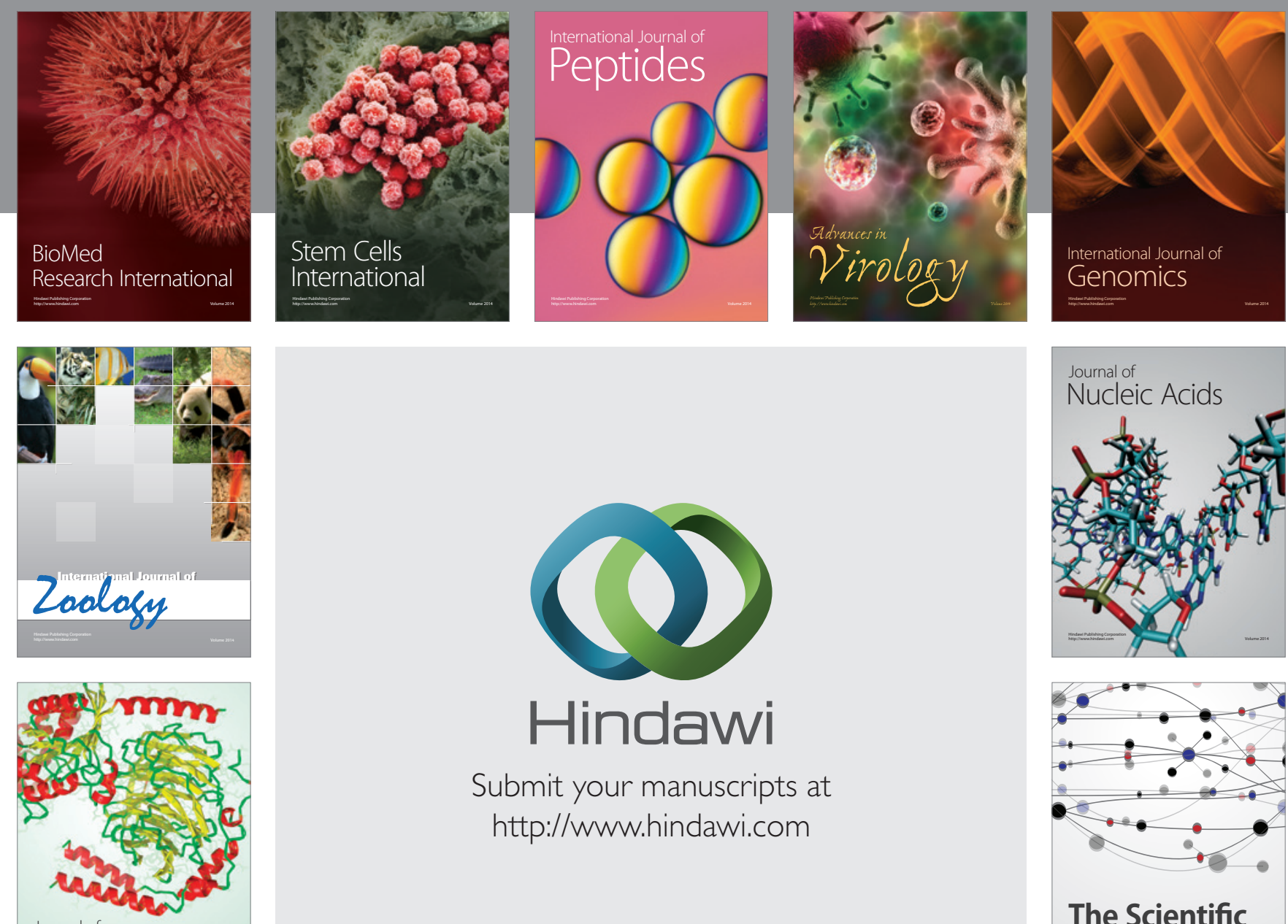

Submit your manuscripts at

http://www.hindawi.com

Journal of
Signal Transduction
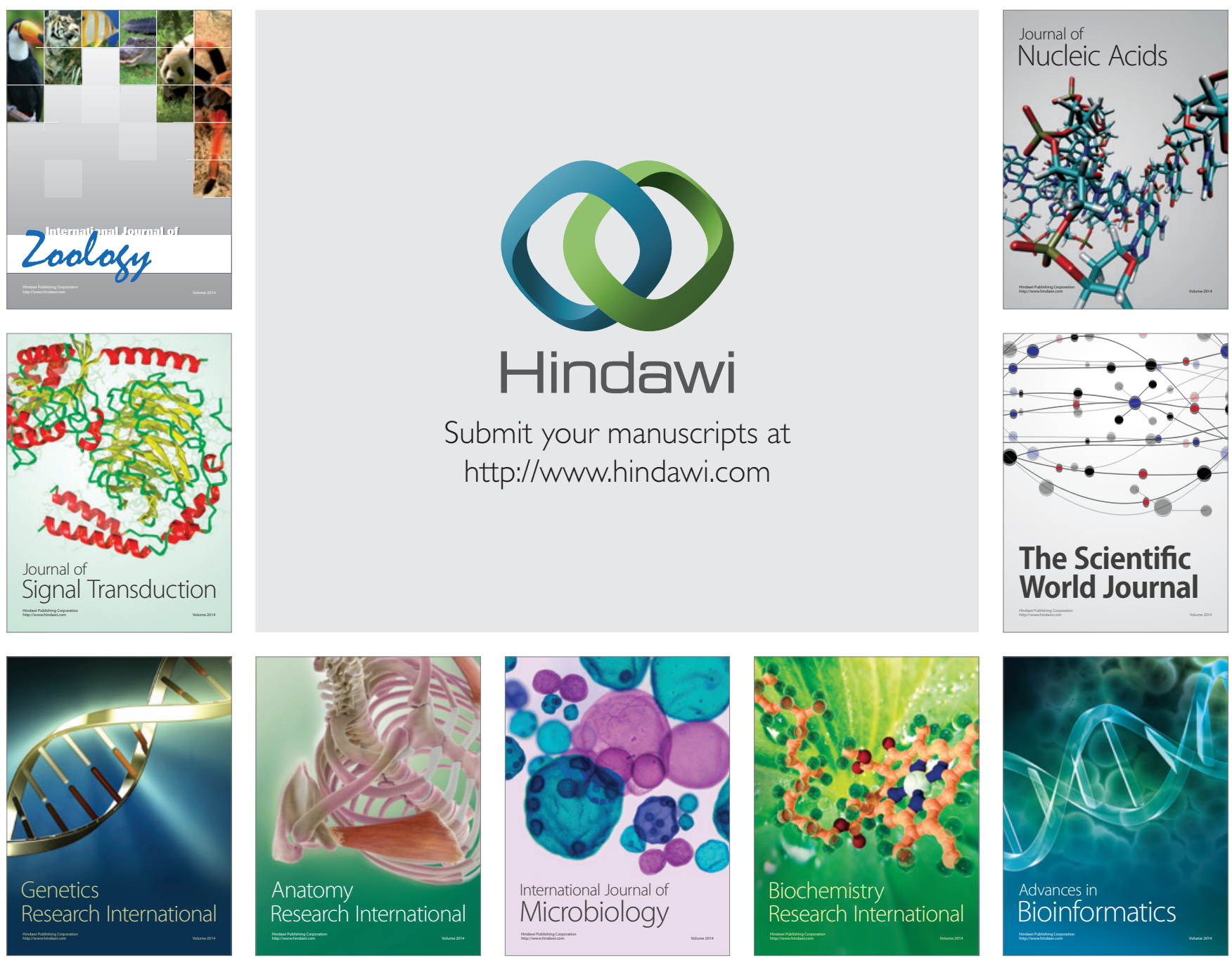

The Scientific World Journal
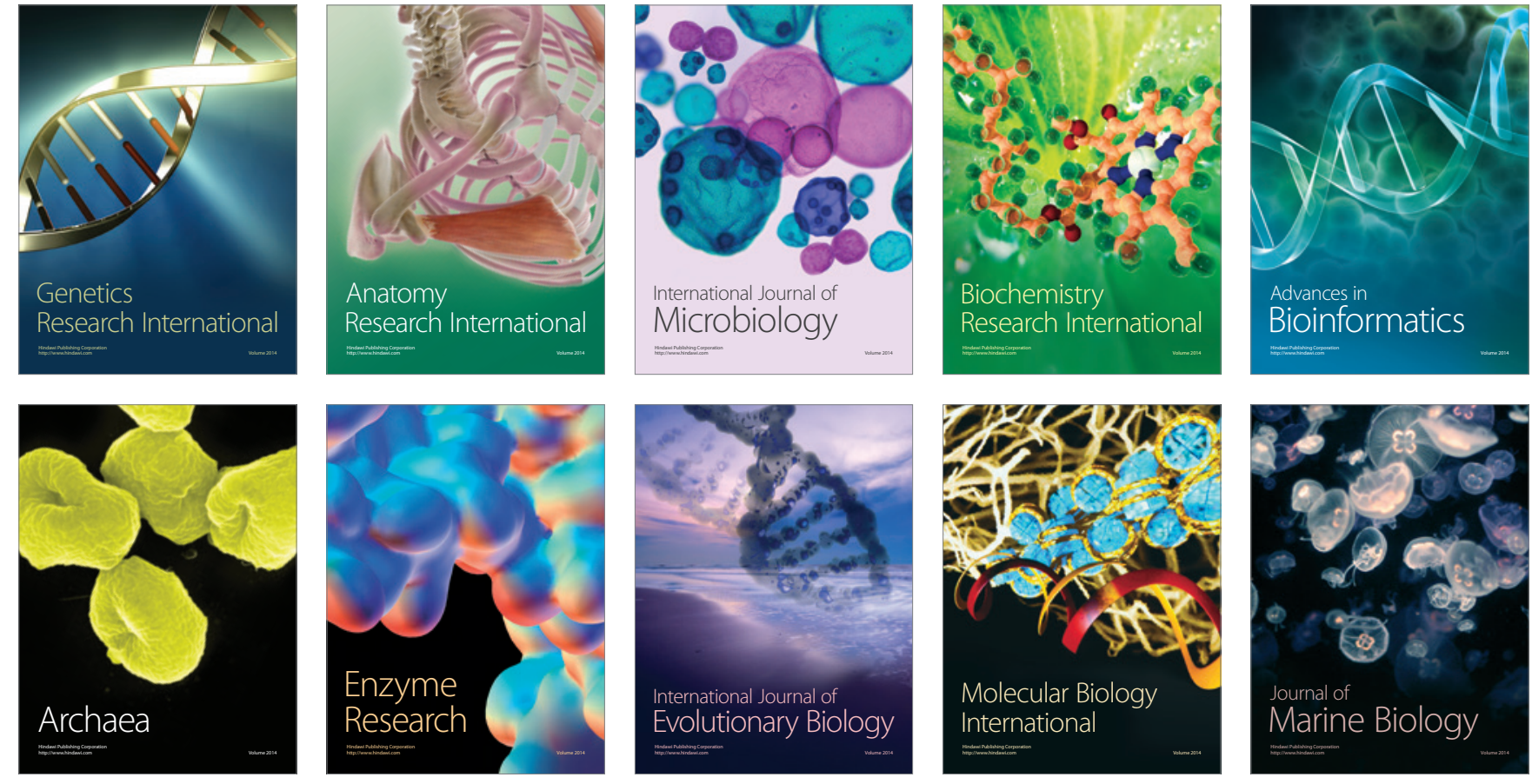